\title{
THE ORGANIZATION OF AFRICAN UNITY AND THE POLICY OF „DÉTENTE“ IN SOUTHERN AFRICA
}

\author{
By Zdenek Červenka
}

The emergence of the so-called policy of "détente" in 1974-75 was probably one of the most significant chapters in the twelve years long life of the Organization of African Unity. The policy of "détente" constituted a serious effort on part of four members of the Organization of African Unity, Zambia, Tanzania, Botswana and Mozambique acting under the aegis of the Organization, to secure peace in Southern Africa. They were exploring ways and means as to how the objectives of the OAU, namely the transfer of power to African majority in Rhodesia and Namibia and the ending of apartheid in South Africa, could be achieved peacefully rather than by the use of violence. The policy of "détente" evolved from the contacts between the Heads of State of Zambia, Tanzania, Botswana and Mozambique on one hand and the South African Premier Vorster and the Rhodesian Prime Minister Ian Smith on the other. The negotiation was focused on Rhodesia which became the test case of the viability of "déntent", a test which "détente" did not pass.

Reaching the headlines of mass media in October 1974 the policy of "détente" raised high hopes for an early settlement in Rhodesia and for an early withdrawal of South Africa from Namibia. Optimism was spread even about the changes within South Africa itself. All these hopes died as quickly as they were born. After barely six months of being the most used term in African diplomacy, the policy of "détente" was declared by the OAU as "nonsense, which should be treated with the contempt it deserves".

The following article explaines the foundations of the OAU policy on Southern Africa and the OAU objectives in the area stipulated by the Lusaka Manifesto of 1969. It also examines the South African response to the OAU initiative, namely the "outward policy" which led at first to the proposal of "dialogue" with South Africa and subsequently to the policy of "détente".

\section{Foundations of the OAU policy on Southern Africa}

The foundations of the OAU policy on Southern Africa, which encompasses the white minority regimes of South Africa and Rhodesia and which, at the time when the OAU came into existence in 1963, included also the largest colonial empire of Portugal, were laid down by the OAU Charter which declares as one of its purposes "to eradicate all forms of colonialism in Africa" and by the two principle resolutions adopted at the same time with the OAU Charter on 25th May 1963 in Addis Ababa: Resolution on decolonization and the Resolution on apartheid and racial discrimination ${ }^{1}$. The resolution of decolonization is the more important of the two. In its declaratory part the member States reaffirm their duties to support dependent people in Africa in their struggle for freedom and

\footnotetext{
1 The Summit Conference of Independent African States, Addis Ababa, May 1963: Agenda Item II: Decolonization (CIAS/Plen/2/rev. 2).
} 
independence. They describe colonialism as "the forcible imposition of the colonial powers of the settlers to control the governments and administrations of the dependent territories which is a flagrant violation of the inalienable rights of the legitimate inhabitants of the territories concerned". In the operative part the founding fathers of the OAU agreed on the following measures:

1. To send an OAU delegation to the United Nations to plead the case if dependent territories with the Security Council.

2. To break off diplomatic and consular relations between all African States and South Africa and Portugal.

3. To institute a boycott of the foreign trade of Portugal and South Africa by

(a) prohibiting the import of goods from those two countries

(b) closing African ports and air ports to their ships and planes

(c) forbidding the planes of those two countries to overfly the territories of all African States.

4. To establish a Liberation Committee (officially called the Coordinating Committee responsible for harmonizing the assistance from African States and for managing the Special Fund to be set up for that Purpose) with headquarters in Dar es Salaam.

5. To provide liberation movements free transit, material aid and assistance in various fields by bodies of volunteers established in each country.

The resolution on apartheid and racial discrimination is largely complementary to that on colonialism. It expresses "imperious and urgent necessity of co-ordinating and intensifying their efforts to put an end to South African government's criminal policy of apartheid and wipe out racial discrimination in all its forms".

Both resolutions make it clear that the founding fathers of the Organisation of African Unity regarded South Africa as the key to the liberation of Southern Africa and to the restoration of the dignity of African people humiliated by the racial discrimination practised both by South Africa and Rhodesia, and as Africa's chief enemy against which concerted actions were being directed also at the United Nations.

For Africans apartheid became a symbol of a "crime against humanity, a flagrant violation of the principles of the United Nations and a massive and ruthless denial of human rights constituting a threat to peace"2", committed and perpetuated by South Africa. Concurrently, the rule of the white minority of less than 4 million over 15 million Africans was being regarded as possessing all characteristics of a colonial rule. For OAU the task of elimination of apartheid was therefore an integral part of the global task of decolonization of the African continent to which South Africa was the regarded to be the main obstacle. The OAU's perception of South Africa's role in this respect has remained unaltered. Twelve years after the adoption of the resolutions on decolonization and apartheid in 1963, the "Dar es Salaam Declaration on Southern Africa" adopted by the 9th Extraordinary

\footnotetext{
2 Resolution on apartheid and racial discrimination adopted by the OAU Council of Ministers in Kishasa, in September 1967 CM/Res. 102 (IX).

OAU's view of apartheid was upheld by number of international conferences. The most important was the Teheran Conference on the Human Rights in 1968.

The Proclamation of Teheran adopted on 13th May 1968 stated the following:

"Gross denials of human rights under the repugnant policy of apartheid is a matter of the gravest concern to the international community. This policy of apartheid, condemned as a crime against humanity, continues seriously to disturb international peace and security. It is therefore imperative for the international community to use every possible means to eradicate this evil. The struggle against apartheid is recognized as legitimate."

For the text of the Teheran Declaration, see UN publication issued on the 25th Anniversary of the Universal Declaration of Human Rights entitled „Human Rights“, New York: United Nations, 1973.
} 
session of the Council of Ministers in Dar es Salaam in April 1975 made the following analysis of the situation in Southern Africa:

"There are two main areas of conflict in southern Africa. The first is the confrontation with colonialism. The second is the conflict with the system of apartheid which has rightly been declared by the United Nations as a crime against humanity. But whether we are dealing with the struggle against colonialism in Rhodesia or illegal occupation of Namibia or racist domination im South Africa, the main opponent of Africa is the same: the South Africa regime and the power it wields in the three areas. Thus the southern African problem is firstly South Africa as a colonialist power, and secondly South Africa as a racist society ${ }^{3}$."

OAU's policy on South Africa has been fourfold:

1. Adoption of measures by the African states themselves; the severence of diplomatic relations with South Africa, the imposition of an economic blockade, the accommodation of refugees from South Africa, and support for the liberation movements within South Africa.

2. Diplomatic pressure on non-African states, notably on the Western Powers: United States, Great Britain, France, Federal Republic of Germany and Japan to comply with the UN aims embargo on South Africa and cease all activities increasing the economic and military potential of the Pretoria regime.

3. A world-wide campaign "to explain and provide information on the true nature and terrible effects of the policy of apartheid"'.

4. Sustained efforts at the United Nations aimed at the expulsion of South Africa from the United Nations.

However, it has become clear from the very onset of the African campaign against South Africa that its success ultimately depends on the attitude of the Great Powers, permanent members of the United Nations Security Council, which in terms of "real politics" virtue of their economic and military strength have a decisive say on any international issue both inside and outside the United Nations.

Two of the permanent members of the Security Council - Great Britain and France were the chief architects of colonialism in Africa. Three of them, Great Britain, France and the United States are the main trading partners of South Africa and the principal investors in South African business. All three were also allies of Portugal through common membership in NATO as well as through common trade and business interests ${ }^{5}$.

The African leaders were certainly fully aware of this. In their Addis Ababa resolution on decolonization of 1963 they appealed to the Great Powers to cease "to lend direct or indirect support or assistance to all those colonialist governments which might use such assistance to suppress national liberation movements".

3 The text of the Dar es Salaam Declaration was published by the UN Department of Political and Security Council Affairs (UNIT ON APARTHEID) No. 19/75 in May 1975. (ECM/St. 15 [IX]).

4 The OAU initiated holding of an international conference of experts on colonialism and apartheid in southern Africa in Oslo 9-14 April 1973 jointly with the United Nations. The agenda of the Oslo Conference included an assesment of the situation in the various fields of action on decolonization and apartheid. For the conference proceedings see SOUTHERN AFRICA (The UN-OAU Conference, OSLO 9-14 April 1973) edited by Oloav Stokke \& Carl Widstrand, Uppsala: The Scandinavian OSLO 9-14 April 1973) edited by Oloav
Institute of Africains Studies, 1973 (2 volumes).

5 About 22 per cent of South Africa's industry is foreign-controlled, chiefly by US and British About 22 per cent of South Africa's industry is foreign-controlled, chiefly by US and British US and British capital are in control of the majority of investments throughout the area: the Anglo-American Corporation of South Africa (multinational), Charter Consolidated (Uk), which is a merger of two concerns; and the selection Trust and Lonrho (Uk). In addition, six large mining companies are a major force in the economy. Among these are De Beers Consolidated Mines, owned by the Oppenheimer concern, which controls 80 per cent of the world's diamond trade, and related Anglo-American Corporation which controls 40 per cent of South Africa's gold products. 
Portugal was singled out as the most glaring example of colonial oppression while South Africa, though not named, fell into the category of "colonialist governments". The resolution on apartheid and racial discrimination was more specific on that point. It appealed to the trading partners of South Africa to cease their support for the apartheid regime and appealed to all governments with diplomatic consular and economic relations with the Government of South Africa: "to break off those relations and to cease any other form of encouragement of apartheid".

The OAU, enouraged by the conclusions of the International Conference on Economic Sanctions against South Africa held in London in 1964 that "the adverse effects of a policy of collective sanctions on world trade, finance and on the economies of individual countries having a significant share in the South African economy would be small and marginal, and arguments that vital economic interests are at stake are highly exaggerated ${ }^{6}$ ", demanded imposition of economic sanctions but France, Great Britain and the United States would not even consider it. Gradually, OAU's appeals gave way to expressions of concern, regret, and finally to strong condemnation. During 1964, OAU appealed to the major trading partners of South Africa "to discontinue the encouragement they are giving to the maintenance of apartheid by their investments and commercial relations with the Pretoria Government ${ }^{7}$ ". One year later, at the OAU Summit in Accra, the Heads of State urged all states to institute a strict embargo on the supply of arms to South Africa, and asked France in particular to cease forthwith the supply of military equipment to South Africa. In 1965 the Accra OAU Summit launched a special appeal "to the major trading partners of the Republic of South Africa particularly the United Kingdom, the United States, Japan, the Federal Republic of Germany, Italy and France - to discontinue their growing economic collaboration with the South African Government, since such collaboration encourages it to defy world opinion and to accelerate the implementation of the policy of apartheid" 8 .

During 1967, OAU concluded that the direct responsibility for the aggravation of the situation in South Africa lay with the principal trading partners of South Africa - especially three of the permanent members of the Security Council for their refusal to comply with the recommendations of the UN General Assembly and OAU9.

The 1968 OAU Summit "condemned unreservedly" Great Britain, the United States, France, Western Germany and Japan for their "continued political and military collaboration with the South African regime" which made it possible for South Africa to persist with its racial policies. Western Germany, Italy and France were also condemned for selling military equipment to South Africa and assisting South Africa in the production of ammunition and poisonous gas ${ }^{10}$. Two years later, the OAU warned these states that "any form of military or other co-operation with South Africa, Rhodesia and Portugal constitutes a hostile act against all African States and their peoples"11".

6 For the proceedings of the conference see "Sanctions against South Africa", edited by Ronald. Segal, London: Penguin. Books, 1964.

7 Apartheid and racial discrimination in the Republic of South Africa CM/Res. 66 (V).

8 Resolution on "Apartheid in South Africa" adopted at the second ordinary session of the Council of Ministers held in Lagos from 24 to 29 February 1964. CM/Res. 13 (II).

9 Resolution on apartheid and racial discrimination adopted by the Council of Ministers at its ninth ordinary session in Kinshasa in September 1967 CM/Res. 102 (IX).

10 Resolution on apartheid and racial discrimination adopted by the Council of Ministers at its tenth

11 Resolution. on apartheid and racial discrimination adopted by the Council of Ministers at its fifteenth ordinary session. in Addis Ababa in August 1970. 
In 1971, OAU repeated its call for a world-wide campaign with the following objectives:

a) the cessation of all military co-operation with South Africa,

b) the boycott of South Africa in economic, cultural, and other fields,

c) the ending of torture in South African prisons and the release of all political prisoners,

d) to apply to freedom fighters the relevant articles of the Geneva Conventions of 1949 on the treatment of prisoners of war and to ensure the participation of liberation movements in the drafting and application of international law applicable to the internal conflict,

e) the imposition of sanctions on companies investing in South Africa,

f) the prohibition of forced emigration, especially in respect of skilled workers, to South Africa ${ }^{12}$.

The resolution on South Africa adopted at the tenth OAU Summit in Addis Ababa in May 1973 reiterated its concern about the "repressive measures of the South African minority racist regime against the African people in this territory" and its contention that the "massive military build-up of South Africa constitutes a threat to peace and security in Africa". It also pledges "to increase its financial and material assistance to the National Liberation Movement of South Africa". The continued economic and military assistance to South Africa by NATO Powers is condemned on the grounds that "it enabled the Pretoria's regime to maintain and even expand its apartheid policy". It rejects the contention that economic, financial and cultural links with South Africa could lead to a rescindment of the apartheid policy ${ }^{13}$.

The resolution on sanctions against the white minority regimes in Southern Africa adopted in 1975 at the 12th OAU Summit at Kampala is very explicit in voicing Africa's disappointment with the attitude of Western Powers. They are held directly responsible for the survival of the regimes in South Africa and Rhodesia due to their "decisive political economic and military support ${ }^{14}$."

The Intransigency of the Western Powers over South Africa has of course also its strategic military motivations enhanced by two factors:

1. The closure of the Suez Canal between 1967-1975;

2. The presence of the Soviet Navy in the Indian Ocean.

During the closure of the Suez Canal between 1967-1975 the sea-route around the Cape of Good Hope assumed a vital importance to the West, both for oil supplies and for Western military strategy in the Indian Ocean.

The October War in 1973 between Israel, Syria and Egypt, and the ensuing Arab oil boycott against the United States, Western Europe and South Africa, suddenly highlighted the strategic position of the cape route and provided yet another argument to South Africa which persistently tried to win the recognition as an important ally of the West. A possibility that the "vacuum" in the Indian Ocean after British withdrawal from east of Suez might be filled by the Soviet Union was

$12 \mathrm{CM} /$ Res. 242 (XVII) adopted at the seventeenth ordinary session of the Council of Ministers in Addis Ababa in June 1971.

13 Resolution on South Africa (CM/Res. 299) (XXI).

14 The resolution urges the Western Powers, particularly the United States, Great Britain, France, the Federal Republic of Germany, Switzerland and Japan to end immediately all cooperation with the regimes in Pretoria and Salisbury by respecting the various United Nations resolutions on regimes in Pretoria and Salisbury by respecting the various United Nations resolutions on
international sanctions. It further invites "all member States to take individual and collective action with the Western Powers and Japan in order to persuade them to stop immediately the massive support they continue to grant the racist minority regimes of Southern Africa". CM/Res. 422 (XXV). 
another one. This was expressed, for example by Admiral H. H. Biermann, the Commander-in-Chief of the South African Defence Force as follows:

"Communist penetration into the Southern Hemisphere, and the threats that this portends, have caused the Southern Hemisphere, and particularly the Indian Ocean to emerge dramatically from a position of relative obscurity and to assume conspicuous position in the East-West power struggle. The focal point in this changed perspective is occupied by Southern Africa - and the Republic of South Africa ${ }^{15}$."

The third argument of South African diplomacy was to present the African opposition against the white minority rule as "communist inspired", and the Soviet and Chinese presence in Africa as a preparation for "conquest of strategic countries". However, these arguments as plausible as they were to the NATO military thinkers were wearing thin under the impact of the exposure of the nature of South Africa's policy of apartheid and its intransignecy over Namibia in particular at the United Nations.

This in turn became increasingly difficult for the Western Powers to justify their continuing support for the Pretoria regime. At the same time, it became obvious to a large part of the Western world that their societies were dependent not only on oil but other raw materials as well and that a sudden cut of their supplies could cause severe economic disruption ${ }^{16}$. The collapse of the Portugal colonial empire coupled with the growing economic dependency of Western industries on the raw materials of South Africa's adversaries created a new situation which the Western Powers simply could not afford to ignore.

The turning point came on October 25, 1974 when three African members of the Security Council - Cameroon, Kenya and Mauritania tabled a resolution calling for the immediate expulsion of South Africa from the United Nations. Although the move was blocked by the triple veto of the United States, Great Britain and Africa (the first time ever the three countries had cast their veto together), it was made clear that in exchange for their veto they would expect a tangible proof that South Africa would begin to eradicate its racial injustices and withdraw from Namibia otherwise it may not count their veto in the future ${ }^{17}$.

\section{Lusaka Manifesto}

An important African initiative on decolonisation and apartheid was the "Lusaka Manifesto on Southern Africa". It is a joint statement agreed upon by representatives of Burundi, Central African Republic, Chad, Congo, Ethiopia, Kenya, Rwanda, Somalia, Sudan, Tanzania, Uganda, Zaire and Zambia at the Conference of East and Central African States in April $1969^{18}$.

15 Quoted by Signe Landgren in Southern Africa: The Escalation of a Conflict, Stockholm: SIPRI, 1975. For more details on the military strategy in Southern Africa see also J. E. Spence: The Political and Military Framework, London: Africa Publication Trust, 1975

16 Before the oil crisis in 1973, the monthly total volume of oil shipped around the Cape amounted to some 20 million tons, of which about 90 per cent was destined for European ports. About 20,000 ships a year call at the Cape, and another 14,000 pass without calling. The large supertankers carrying the oil of up to $350,000 \mathrm{dwt}$. will have to continue to use the Cape Route aiso after the reopening of the Suez Canal in 1975 as the Canal is limited to ships in the 60,000 dwt class at most.

17 In their own draft resolution the Western Powers called on South Africa to make immediate and broad concessions along three lines:

a) Withdrawal of all South African military forces from Rhodesia,

b) Progress on the negotiation for self-determination of South West Africa (Namibia),

c) The repeal of certain domestic legislation involving apartheid.

18 The text of the Lusaka Manifesto was published in Africa Contemporary Record (Annual Survey and 
The purpose of the Manifesto was, first of all, to explain Africa's reasons for its united opposition to the racialist policies of the Government of South Africa. Secondly, the Manifesto constituted a serious effort on part of Africans to achieve their objectives in Southern Africa: decolonisation and elimination of racial discrimination by peaceful means rather than by armed struggle.

"Our objectives in Southern Africa", states the Manifesto, "stem from our commitment to this principle of human equality. We are not hostile to the Administrations of these States because they are manned and controlled by white people. We are hostile to them because they are systems of minority control which exist as a result of, and in the pursuance of, doctrines of human inequality. What we are working for is the right of self-determination for the people of those territories. We are working for a rule in those countries which is based on the will of all the people, and an acceptance of the equality of every citizen".

The Manifesto asserts that the Republic of South Africa is an independent state "more highly developed and richer than any other nation in Africa". The Manifesto, while recognizing that "on every legal basis its internal affairs are a matter exclusively for the people of South Africa" it makes it clear that the policy of apartheid exceeds the limits of "internal affairs" and are of a rightful concern to the international community. "The purpose of law is people", says the Manifesto, "and we assert that the actions of the South African Government are such that the rest of the world has a responsibility to take some action in defence of humanity".

The African objectives in Southern Africa are specified as

1. That the people in the territories still under colonial rule shall be free to determine for themselves their own institutions of selfgovernment.

2. That the individuals in Southern Africa shall be freed from any environment poisoned by the propaganda of racialism, and given an opportunity to be men not white men, brown men, yellow men or black men.

The Lusaka Manifesto goes on to say that, for this purpose, "we would prefer to negotiate rather than destroy, to talk rather than kill. But while peaceful progress is blocked by actions of those at present in power in the States of Southern Africa, we have no choice but to give to the peoples of those territories all the support of which we are capable in their struggle against their oppressors. This is why the signatory states participate in the movement for the liberation of Africa under the aegis of the Organization of African Unity."

Thus, the Lusaka Manifesto makes it clear that the strategy of armed resistance has been accepted by Africa with reluctance. It points out that peaceful progress towards the implementation of the principles of human equality and self-determination is not possible if those in power reject those principles and relentlessly suppress any attempt to further them by peaceful means.

The Lusaka Manifesto was endorsed by the OAU Summit meeting and presented to the 24th Session of the General Assembly of the United Nations later the same year by President Ahmadou Ahidjo in his capacity of the Chairman of the OAU. Out of then $126 \mathrm{UN}$ members only South Africa and Portugal voted against it.

Documents) 1969-1970 edited by Colin Legum and John Drysdale, London: Africa Research Ltd, 1970, pp. C $41-C 45$. 
South African response to Lusaka Manifesto: the policy of "dialogue”.

The concept of "dialogue" was evolved in South Africa as a component of so called "outward looking policies" designed to counter the diplomatic offensive of the signatories of the Lusaka Manifesto.

Six months after the adoption of Lusaka Manifesto the South African Foreign Minister Dr. Hilgard Muller in his address to the United Nations in October 1969 said that

"dialogue with other African states would grow in future, despite the Republic's policy of separate development ... We have a great deal of cooperation in Southern Africa, whether it be with white or independent African countries. And that bilateral and multilateral dialogue will grow ${ }^{19}$."

Dr. Muller was referring to the relationship of South Africa with Malawi, whose President Dr. Hastings Banda established diplomatic relations with South Africa in defiance with the OAU policy since 1966.

In 1969 Dr. Muller had told his parliament that the Government was in direct touch with considerably more African Governments than he was then prepared to reveal. But the policy of dialogue began to come under heavy attack from the verkrampte element within the Nationalist Party. In a typical defence of South Africa's aims and interests, the then Minister of Immigration, Dr. Connie Mulder, said during the 1970 election campaign: "Africa does not have problems; it only has challenges. Africa is our fatherland and our future, and we are going to play a role in Africa because it is in our interests to do so ... I see an even greater vision further to the north. The high point for Africa still lies ahead, and the day will come when Africa reaches its high point and when it will form the empire that will rule and dominate the world. In that Africa, South Africa and the white man will play an extremely important role because we have the knowledge of Europe tempered with 300 years in Africa. When that day comes, the few whites of South Africa will play a role out of all proportion to their numbers or their wealth" ${ }^{20}$ ".

South African expectations of a breakthrough of its isolation imposed on it by the Organisation of African Unity were based not only on its relations with Dr. Banda but also on the contacts with President Kaunda of Zambia which started in 1968.

President Kaunda though responding favourable to Prime Minister Vorster's initiative to hold a meeting between the two, was very careful to make it clear that no useful purpose would be served by a meeting unless there were some indication of the SA Government's willingness "to initiate measures to bring about a change in the current policies in order to harmonize the relations between human beings of different races and colour".

But the "South African-Zambian" communications were brought to an end on 29th August 1968 when President Kaunda refused Premier Vorster's proposal for a meeting with one of his representatives to discuss possible settlement in Rhodesia. Mr. Vorster later on choose to disclose the correspondence in order to discredit Dr. Kaunda but it certainly did more harm to him than to the Zambian Presi$\operatorname{dent}^{21}$.

19 Quoted by Colin Legum in his article "Dialogue: The Great Debate", in: Africa Contemporary Record (Annual Survey and Documents 1971-1972, London: Rex Collings, 1972, pp. A 66-A 82. 20 ibid.

21 This exchange had its repercussions in 1971 when Mr. Vorster chose to ignore diplomatic practice by increasing part of the correspondence without previous consultation in a clear attempt to discredit $\mathrm{Dr}$. Kaunda on the eve of an important statement by President Houphouet-Borgny. Mr. Vorster simply told his parliament that he wished to expose the "hypocrisy of Dr. Kaunda who was opposing those willing to enter into a dialogue whereas he himself had in fact engaged in correspondence". The 
After these preliminary ouvertures the stage for the "dialogue" was finally set by the Ivory Coast President Houphoet-Boigny at his press conference on 6 November 1970. He proposed to launch a "peace mission" to get agreement from his fellow Heads of States to "help the South African whites to enter into dialogue with their own blacks". However, he insisted that he would take no independent initiative towards Pretoria, and that he would operate only through, and in cooperation with, the OAU after consulting members of the Organization for the Community of African, Malagasy and Mauritian states (OCAM). He elaborated on his fears about the danger to peace in the African continent, particularly because of the communists. The key point in his statement was: "I believe the dialogue with the white citizens of South Africa is feasible, if it is carried out in a perspective of peace through neutrality, in an atmosphere of political neutrality, peace which is of concern to all Africans, to the white population of South Africa as well as ourselves22".

His initiative was supported by the members of the "Entente Council" (Upper Volta, Dahomey, Niger and Togo) as well as by Gabon, Central African Republic, Lesotho, Madagascar, Swaziland and Malawi. However, it should be pointed out that each of the Heads of State and Government of the countries emphasized that "while we condemn racial discrimination and apartheid, another way besides armed struggle should be found to achieve our objective ${ }^{23}$ ".

The issue of "dialogue" described by the "Ethiopian Herald" as Africa's "great Debate" dominated the proceedings of the 1971 OAU Summit at Addis Ababa. Already prior to the meeting the opponents of dialogue which included Nigeria, Ethiopia, Kenya and Tanzania launched a diplomatic counteroffensive.

In this respect the meeting between Major-General Gowon, the Head of the Military Government of Nigeria, and Emperor Haile Selassie of Ethiopia which took place from 4 to 8 May 1971 was of particular significance. It laid down the rules according to which the "dialogue policy" was to be treated by the forthcoming sessions of the OAU's Council of Ministers and the Assembly of Heads of State and Government.

In their joint communique of 8 Mai 1971 they stated in clear terms that the only basis for dialogue with South Africa could be the Lusaka Manifesto. Speaking at a banquet in his honour, Major-General Gowon said: "It will be a great betrayal if we only pay lip service to the cause of liberation of the people of South Africa or if we assume that we can restore their dignity by bargaining on economic or other selfish grounds with their oppressors." He added: "Nigeria will not be a party to any dialogue with those whose only aim is to divide our ranks and subjugate our brothers, forever, in servitude and degradation ${ }^{24}$."

Similar unity of views was reached during General Gowon's visit to Kenya four days later with President Jomo Kenyatta. Their joint communique of 12 May expressly condemns dialogue stating that "there could be no meaningful dialogue which was not based on human equality and dignity as envisaged in the Lusaka Manifesto $25 "$.

point he failed to make, was that Dr. Kaunda's correspondence was plainly intended to establish the basis for dicussions along the lines of the Lusaka Manifesto; it was not, in fact, a pursuance of dialogue itself. In the end, Mr. Vorster did more damage to his own cause than to Kaunda's; even M. Houphouet-Boigny sharply criticized him for breaking confidence; ibid.

22 Le Monde, Paris, 7 November 1970.

23 President Maga of Dahomey at the meeting of the Entente Council in Ougadougou quoted by Colin Legum opus cit.

24 "Ethiopian Herald, Addis Ababa, May 9, 1971

25 Press Release of the Nigerian Federal Ministry of Information No. 466, 12 May 1971. 
The Nigerian initiative was prompted by a statement by President HouphouetBoigny of the Ivory Coast at an international press conference in Abidjan on 28th April 1971 where he officially confirmed that he was to pursue "dialogue" with South Africa. Although he endorsed Lusaka Manifesto the went on to say: "After due consideration I think it is possible to have a dialogue with South Africa ${ }^{26}$."

The issue of the "dialogue" dominated the agenda of the 1971 OAU Summit in Addis Ababa where it was introduced by Ivory Coast. But the outcome of the debate was quite contrary to the expectations of the Western observers. The Western mass media which were giving the "dialogue" a publicity out of the proportion to its real bearing on Africa and describing it as "the only alternative left" were proved to be wrong ${ }^{27}$.

The prevailing mood in respect of the dialogue with South Africa, was amply shown early in the debate on the wording of this item on the agenda of the Council. The proposal of the Ivory Coast to have the matter inscribed as "peace through neutrality" was defeated in favour of the Tanzanian proposal: "The principles of the OAU, the Lusaka Manifesto, Dialogue and future Strategy of Africa". The walk-out of the Ivory Coast delegation and the decision of Upper Volta, Togo, Dahomey and Gabon not to participate in the debate on the matter, had not blunted the sharpness of "The Declaration on the Question of Dialogue28". It was adopted by 27 votes against 4 (Lesotho, Madagascar, Swaziland and Malawi) and two abstentions (Dahomey and Niger) with Ivory Coast, Upper Volta and Gabon not taking part in the voting and the other members of the OAU being absent (Uganda, Central African Republic, Republic of Zaire and Mauritius). In the Declaration, the Council rejected "dialogue with South Africa" describing it as a "manoeuvre by that regime and its allies to divide African States, confuse world public opinion, relieve South Africa from international ostracism and isolation and obtain an acceptance of the status quo in South Africa".

The Declaration reiterates the commitment ot the principles and purposes of the OAU Charter and points out that the Lusaka Manifesto is the only possible basis for any meaningful solution to the problems of apartheid, racial discrimination and colonialism in Africa. Should there be any dialogue at all, then, according to the Declaration, "it should appropirately be commenced only between the minority racist regime of South Africa and the people they are oppressing, exploiting and suppressing". Perhaps the most important provision of the Declaration has been the clearly stipulated obligation demanding that "no Member State of the OAU would initiate or engage in any type of activity that would undermine or abrogate the solemn obligations and undertakings to the commitments in the Charter", and that any such action could be taken by the member State only "with the guidance, consent and approval of the Organization". In other words, the right to independent opinion and to the independent foreign policy of each member State does not apply to "dialogue", qualified by the Declaration as a policy contrary to the very purposes and principles of the OAU Charter.

The Declaration has made it clear that from now on any State pursuing the policy of dialogue is acting contrary to the principles of the Charter and defying an expressly and strongly formulated opinion of the qualified majority of the OAU members.

26 Le Monde, Paris, April 29, 1971.

27 See also author's article "The Organisation of African Unity in the seventies". In: "Verfassung und Recht in Ưbersee", Hamburg, 1972, pp. 29-39.

$28 \mathrm{CM} / \mathrm{St} .5$ (XVII) 
The OAU Summit endorsed two other resolutions concerning South Africa submitted by the Council of Ministers, namely the "Resolution on apartheid and racial discrimination" and the resolution requesting the "Convening of a special session in Africa of the United Nations Security Council on De-colonization problems 29 ". The first calls for a world-wide campaign against South Africa and her boycott in military, economic, cultural and other fields, and for action against companies investing in South Africa, and prohibition of the emigration of skilled workers to South Africa. The other calls for a special session of the Security Council to be held in 1972 in Africa "devoted solely to the measures to be taken with a view to implementing the various Security Council and General Assembly resolutions on de-colonization, the struggle against apartheid, racial discrimination in Africa, and the withdrawal of foreign occupation zones from African soil".

Although Ivory Coast, Malawi and Gabon refused to abide the OAU rejection of the "dialogue" and President Banda of Malawi became the first African Head of State ever to pay an official visit to South Africa in August 1971 other supporters of the "dialogue" began to have doubts and some of them, such as Ghana after Dr. Busia's overthrow in 1971 reiterated its uncompromising support for the OAU policy on South Africa.

When the 1972 OAU Summit was convened to Rabat, "dialogue" was already a dead issue, which was not even mentioned at the meeting.

\section{Mogadishu Declaration}

The rejection of the "dialogue" with South Africa by the OAU was reaffirmed also by the signatories of the Lusaka Manifesto at the 7th Summit Conference of East and Central African States at Mogadishu in October 1971. In a document called "Mogadishu Declaration" ${ }^{30}$ " the leaders of East and Central African States reviewed the developments since the adoption of the Lusaka Manifesto and its rejection by South Africa and Portugal. The concluded that "there is no way left to the liberation of Southern Africa except armed struggle to which we already give and will increasingly continue to give our fullest support". They have resolved to increase their assistance "both material, diplomatic and moral to the national liberation movements until final victory is achieved".

\section{The politics of "détente".}

The collapse of the five centuries old colonial empire of Portugal profoundly changed the balance of power in Southern Africa. The emergence of independent Mocambique and the forthcoming independence of Angola brought the end of the white minority regime in Rhodesia close at hand.

South Africa, deprived of its cordon sanitaire, immediately realized the seriousness of the fact that the frontiers of struggle for the liberation of Namibia as well as against its own regime of apartheid became now those of South Africa itself.

29 Resolution on apartheid and racial discrimination (CM/Res. 242 [XVI]) and Resolution on Convening a Special Session in Africa of the United Nations Security Council on Decolonization Problems (CM/Res. 243 [XVII])

30 The text of the Mogadishu Declaration was published as a UN Document UN/93 (137)) of 23rd February 1972. 
South African Government's first reaction to the new situation was to resume its efforts at establishing contacts with the African leaders who favoured the policy of "dialogue" in 1970-1971 hoping that they would help South Africa to secure peaceful coexistence with its neighbours through "détente". This, if successful would have the added advantage for South Africa avoiding the loss of much needed Western support that would be jeopardized if South Africa got drawn into a military conflict. It is believed that talks were held with Ivory Coast, Senegal, Gabon, Botswana and Malawi"31. An African interest in "détente" had entirely different motivations. The initiative came from Zambia, Tanzania, Botswana and Mozambique whose Presidents met several times since the Lisbon coup d'état on 25th April 1974 to discuss the consequences of Portuguese withdrawal from Mozambique and Angola for Rhodesia. On 10th August 1974 the Foreign Minister of Zambia, Vernon Mwaanga, approached his British colleague, James Callaghan, with a proposal on Rhodesia, the essence of which was a guarantee to be undertaken jointly by the OAU and the British Government of security, personal safety and property of the white Rhodesians who were also offered a participation in the political institutions of Rhodesia. This was subject to an agreement on a peaceful transfer of power to the African majority within a transitional period.

The plan was sympathetically received in London and in Washington where Minister Mwaanga held private talks with the US Secretary of State, Henry Kissinger. Pretoria too indicated interest in the Rhodesian settlement and let know of its willingness to persuade Ian Smith to negotiate the offered terms.

The exploratory secret talks took a new turn under the impact of the African pressure at the United Nations in October 1974 where South Africa was saved from expulsion only due to the triple veto casts by the United States, Great Britain and France.

The South African Premier prompted by the diplomatic disaster at the United Nations delivered so far the most significant speech to his Senate in Cape Town on 23rd October 1974

"Southern Africa", he said, "is at the crossroads and should choose now between peace and escalating violence". The cost of confrontation would be "high - too high for southern Africa to pay". On Rhodesia he said: "It is in the interests of all the parties to find a solution ${ }^{32}$."

On the day following Vorster's speech to his Senate, South Africa's Representative at the UN, Pik Botha, replying to the General Assembly debate on the proposal to expel South Africa, adopted a fresh approach: "Let us not delute ourselves - there are no easy solutions. But my Government stands ready to explore all avenues which may bring about an understanding among us ... He went on to make the statement which was subsequently interpreted as a hint of a crucial change of policy on South Africa's part: "Mr. President, we do have discriminatory practices and we do have discriminatory laws. And it is precisely because of this that the greatest misunderstandings occur and our motives are most misrepresented. But that discrimination, must not be equated with racialism. If we have that discrimination, it is not because the whites in South Africa have any

31 For details see Colin Legum: "Southern Africa: The Secret Diplomacy of Détente". In: Africa Contemporary Record (Annual Survey and Documents 1974-1975), London: Rex Collings, 1975, pp. A 3-A 15.

32 Rand Daily Mail, Johannesburg, 24 October 1974. 
herrenvolk complex. We are not better than the black people, we are not cleverer then they are. What we can achieve, so can they. Those laws and practices are a part of the historical evolution of our country - they were introduced to avoid friction and to promote and protect the interests and the development of every group - not only those of the whites. But I want to state here today very clearly and categorically: My Government does not condone discrimination purely on the grounds of race or colour. Discrimination based solely on the colour of a man's skin cannot be defended. And we shall do everything in our power to move from discrimination based on race or colour... Mr. President, I would mislead you if I were to imply that this will happen overnight. There are schools of thought, traditions and practices which cannot be changed overnight. But we are moving in that direction. We shall continue to do so $^{33}$."

It was this section in Botha's speech, following closely on Vorster's statement of the day before, that led President Kaunda on 26th October to welcome "the voice of reason for which Africa and the rest of the world has been waiting ${ }^{34}$. To persuade Vorster to move further he offered Zambia's help to remove obstacles to peace in the area. Kaunda's response was eagerly followed up by Vorster and his Foreign Minister who said: "It is possible that we are on the threshold of a new era of peace, co-operation and development in southern Africa ${ }^{35}$ ".

These exchanges opened new possibilities for "detente".

Premier Vorster sees "détente" in southern Africa as offering three valuable alternatives:

1. It will reduce the dangers of guerilla warfare;

2. It will help to buy the time he needs to "give apartheid a human face" by promoting independence for his own eight Bantustan Homelands and Namibia in order to create what he likes to describe as a "United Nations of Southern Africa" which would include the independent "black national of South Africa" (the Bantustans) Namibia, Rhodesia, Lesotho, Swaziland, Botswana and hopefully also Mozambique, Angola and Zambia with Pretoria as its political and economic center.

His partners in "détente", namely Presidents Kenneth Kaunda, Julius Nyerere and Seretse Khama did not view the "détente" in quite the same way. They insisted on the independence of Rhodesia under black majority rule as a prerequisite for peace and a test of South Africa's true intentions. They saw a chance of achieving this goal without the dangers of armed struggle. After the settlement in Rhodesia they regard independence of Namibia as the next issue while leaving South Africa's future to be decided at a later stage.

South Africa's consent to make Rhodesia a central issue of the diplomatic negotiations with the four Presidents (subsequently joined by the leaders of Rhodesian nationalist movements) stemmed primarily from South African recognition that the survival of Ian Smith's ten years long regime was no longer possible - not even with South African help.

33 Africa Research Bulletin, London, November 15, 1974, Vol. 11, No. 10 p. 3388. See also an interview with Rudolf Botha in: AFRICA, London, No. 40, December 1974, pp. 18-19. The same issue brings also the views of Edwin Ogbu, Nigeria's Permanent Representative at the UN and Chairman of the UN Committee on Apartheid and of Salim Salim, Tanzania's Permanent Representative at the UN and Chairman of the UN Committee on Decolonization and the Africa Group at the UN.

34 Adress by President Kenneth Kaunda on the occasion of the conferment of the degree of LL.D (Honoris Causa) at the University of Zambia on 26th October 1974 published by the Zambian Ministry of Information under the title "Southern Africa: A Time for Change".

35 Africa Research Bulletin, London, November 15, 1974, Vol. 11, No. 10, p. 3389. 
Intensified guerrilla struggle in Rhodesia into which OAU would put all resources which previously went to FRELIMO and which would be conducted also from military basis in Mozambique and with FRELIMO weapons coupled with the intensification of economic sanctions would require massive military and exonomic rescue operations on part of South Africa, a situation South Africa wished to avoid at any reasonable price. Hence the focus of "détente" on Rhodesia the progress of which went briefly as follows:

1. On 30th October 1974 the London Times quoted "South African Government Sources" that South Africa would be prepared to withdraw its police units from Rhodesia if Zambia agreed to freeze the activities of the guerillas attacking Rhodesia from within its borders.

2. In an Independence Day broadcast on 11th November 1974 the Rhodesian Prime Minister Ian Smith said that "because of new developments emanating from certain other countries there once again appears to be a possibility of settlement".

3. On 3rd December a Rhodesian Government spokesman confirmed reports that the two detained African leaders Reverend Ndabaningi Sithole of the Zimbabwe African National Union (ZANU) and Joshua Nkomo of the Zimbabwe African People's Union (ZAPU) had been temporarily released from detention already in November in order to attend a meeting in Lusaka the nature of which was not specified.

4. Three days later, on 6th December it was disclosed in Lusaka that these talks concerned the future of Zimbabwe and that they were attended also by Bishop Abel Muzorewa, the leader of African National Council (ANC), Robert D. Chikerema of the Front for the Liberation of Zimbabwe (FROLIZI) and the Presidents Dr. Kenneth Kaunda of Zambia, Sir Seretse Khama of Botswana and Julius Nyerere of Tanzania. Later on it was reported that Samora Marchel, President of FRELIMO was also present. At the same time the Rhodesian Prime Minister Ian Smith was believed to have gone for secret talks with Premier Vorster to Pretoria.

5. On December 7, 1974 the Rhodesian Prime Minister's Office issued a statement rejecting the proposal put to the Rhodesian representative by the three presidents who met in Lusaka that the cessation of armed hostilities between the guerrillas and the Rhodesian armed and police forces should be subject to Rhodesia's agreement to convene a constitutional conference to discuss an immediate majority rule in Rhodesia. This was first time the Rhodesian Government publicly admitted that it actually already agreed to hold a constitutional conference with the African political leaders of Rhodesia (a concession which only few months ago was regarded as unthinkable), but insisted on no conditions attached.

6. But the African diplomatic offensive continued. On 9th December it was announced that the movements ZANU, ZAPU, FROLIZI meeting in Lusaka agreed to unite under the leadership of the fourth movement, the African National Council (ANC), to become the only legal African organisation in Rhodesia. Apart from the significance of forming a united movement representing a formidable political force in Rhodesia it also offered Ian Smith a face saving opportunity for continuing negotiations with ANC leader Bishop Musorewa and not necessarily with the leaders of the political parties still officially banned. 
7. The breakthrough came on 11 th December 1974 in a dramatic "adress to the nation" by Ian Smith in which he announced:

a) release of African leaders and their followers from detention

b) ceasefire of hostilities

c) agreement to hold a constitutional conference but without any precondition.

However, he did not omit to add that it was his firm intention not to "deviate from our standards of civilization", which in the plain language of Rhodesians simply means "white rule".

The details of the undertaking made by the Rhodesian government to Presidents Kenneth Kaunda, Julius Nyerere, Seretse Khama and Samora Machel were published later and contained eight points:

a) the immediate release of all political detainees and people in protected villages;

b) the release of all political prisoners as soon as possible;

c) cancellation of death sentrences on political prisoners;

d) the cessation of all political trials;

e) a general amnesty to those outside the country considered to have committed political crimes;

f) lifting of the ban on ZAPU and ZANU and

g) the creation of conditions conducive to free political activity and expression.

At the same time it was agreed to declare ceasefire. Its interpretation however caused considerable difficulties

8. Finally, Great Britain joined the negotiations by supporting the African demands on Rhodesia. In the first week of January 1975, the British Secretary of State Callaghan visited Botswana, Zambia, Tanzania, Malawi and South Africa to talk mainly about Rhodesia. After a meeting with the South African Premier Vorster on 4th January 1975 he stated that he was satisfied that $\mathrm{Mr}$. Vorster can and is exerting pressure on the Rhodesian Government of Ian Smith and that he can persuade him to accept, if necessary a "majority rule within a period of three to five years".

Since February 1975 the optimism about the "détente" began gradually to give way. The hopes about "early settlements" in Rhodesia proved to be unfounded. The Smith's tactics became transparent. He was simply playing on time counting on the fragility of the ANC coalition and its disintegration. Had it not been for the intervention of President Nyerere and Kaunda this would have probably already happened.

Equally futile proved to be the expectations about the change in South African apartheid. The South African Premier gave several public assurances to this white electorate disturbed by his utterances on "détente" that "apartheid is there to stay" ".

It was against the background of "dashed hopes" that an extraordinary session of the OAU Council of Ministers was convened to discuss developments in Southern Africa. 


\section{OAU's new strategy on Southern Africa}

The ninth extraordinary meating of the Council of Ministers of the OAU which met in Dar es Salaam from April 7-10 1975 was important for two reasons:

1. It clearified OAU's stand on the so called "détente" in Southern Africa in its resolution on South Africa.

2. It outlined a new OAU strategy on Southern Africa. This was formulated in the "Dar es Salaam Declaration on Southern Africa" and was unanimously adopted by the conference.

The rumours spread by the South African press that the meeting was convened to discuss "Vorster-Kaunda détente policy" were refuted by the host of the meeting President Julius Nyerere of Tanzania in his opening speech to the assembled Foreign Ministers on 7th April.

"Your Conference will have succeeded", said the Tanzanian President, "if it leaves South Africa in no doubt at all that we are still ready to use peaceful means to achieve independence in Rhodesia and Nambia, but that if this made impossible, we shall resume and intensify the armed struggle. It is important that both our friends and our enemies should know that we mean what we say ${ }^{37}$."

A document submitted to the OAU Conference by Tanzania called "African Strategy in Southern Africa" is perhaps one of the best contemporary political analysis of the situation in southern Africa. On South Africa the document concludes that South African government recognized that pressure against colonialism in Rhodesia and Namibia would increase and become also more effective. It pointed out that South Africa's international legal position became very weak in relation to both and that accepting full responsibility for their defence might weaken the control within South Africa itself, especially as Africans within South Africa show no signs of having become reconciled to the inferior position allocated to them ${ }^{38}$.

The question of the "dialogue" with South Africa was then explained in detail by the Zambian Foreign Minister Vernon Mwaanga. "Zambia and her friends have not been engaged in dialogue", said Minister Mwaanga and continued "After all one can have a dialogue only with a friend. The term détente is not in our vocabulary". He described the negotiations between Zambia and South Africa as contacts and summed up their results as follows:

\footnotetext{
36 Each party was giving its own interpretation to the armistice. In the view of ANC Publicity Secretary Edson Sithole, quoted in the London monthly Africa No. 42 of February 1975 it was understood by the ANC to mean "stopping shooting with no advance beyond the lines where the respective forces were to be found." A proper ceasefire was to be formalized after the date for a constitutional conference was to be fixed. The Rhodesian interpretation was shown by dropping leaflets in the areas of fighting demanding that the guerrillas should abandon their arms and surrender. Those to be found with arms would be treated as enemies. As a result fighting went on, though not on the scale prior to the Lusaka agreement.

37 The full text of President Nyerere speech was published in Daily News, Dar es Salaam, April 9, 1975.

38 The full text of the document was reproduced by the Daily News, Dar es Salaam, 10 April, 1975 . The Tanzanian stand on the talks with South Africa, subsequently endorsed by the OAU, was that while the OAU is prepared to talk with South Africa about Rhodesia and Namibia it refuses to do so on apartheid. The statement put in as follows:

"Talking with the South African government on apartheid is worse than irrelevant. We know what Vorster means by it, we know what it means to the African people of South Africa, as well as to the whole concept of human equality and dignity. Vorster knows what Africa thinks of apartheid. There is no need for any discussion. Further, if and when a South African government decides to change its policies and wants to discuss the new directions with African people, it has no need to use free Africa. Nelson Mandela, Robert Sobukwe and hundreds of other non-white South African leaders are either rotting away physically on Robben Island or in other prisons and places of restriction.

When Vorster decides to release these men and women, to allow peaceful African political activity, and to listen to what they say, we shall know that justice might well triumph in South Africa without the bloodshed we fear. Until those signs are evident we must treat South Africa as on outlaw."
} 
1. The release of the nationalist leader in Rhodesia which was assisted by the South African Prime Minister Vorster.

2. Withdrawal of South African security forces from Rhodesia, for. which the South African Prime Minister has given a date for the final withdrawal.

3. Zambia demanded that South Africa should bring pressure on Ian Smith to negotiate directly with the legitimate leaders of the African people in Rhodesia. There is an evidence that South Africa has really done so.

4. South Africa accepted the inevitability of majority rule in Rhodesia and showed readiness to assist in the peaceful transfer of power in Rhodesia and made it clear that it is no longer in favour of the illegal regime.

Minister Mwaange while acknowledging that "Prime Minister Vorster regardless of our diametrically opposed positions of apartheid has honoured his word on the concrete issues we have dealt with under difficult circumstances" concluded his speech by warning about the dicisions within the OAU itself.

"We are very clear about the manouvres by minority regimes. and the great care we must take in calculating every step", said the Zambian Foreign Minister "but quite frankly we are not the enemy who will divide Africa, limit Africa itself while imperialist merely use the opportunity already provided ${ }^{39}$.

The "Dar es Salaam Declaration on Southern Africa" adopted by the OAU Ministerial Council rejected any dialogue with South Africa by proclaiming that "there is nothing for free Africa to talk to the leaders of the apartheid regime in connection with their policies in South Africa. If the current or future leaders should desire to begin to move away from the policy of racism in South Africa and to seek the co-operation of the Africans to that end, they could initiate the necessary contacts and negotiations from within."

It concluded by reaffirming the determination of the Council of Ministers "to realize the freedom and independence of Rhodesia and Namibia and the total destruction of apartheid and racial discrimination in South Africa". Although the meeting agreed to give negotiations with Rhodesia and South Africa a further chance to produce a settlement in Rhodesia it at the same time also recommended preparations for reversion to guerilla war in case they do not.

It was indeed significant that the South African Prime Minister Vorster chose to reply to the Dar es Salaam Declaration in an exclusive interview with the leading paper in the Federal Republic of Germany - DIE WELT. The West German South African connection has recently assumed significant proportions. The Federal Republic of Germany is to-day South Africa's most important political ally and vitally important business partner ${ }^{40}$. When asked whether he was prepared to negotiate with African States on the basis of the Dar es Salaam Declaration, Prime Minister Vorster replied:

"Most African countries know that the relations between South Africa and most parts of Africa have to be normalized. This is not only in the interests of South Africa but, above all, in their own interests. No doubt there will

\footnotetext{
39 The text of Minister Vernon Mwaanga's speech was published in full by Daily News, Dar es Salaam, April 9, 1975.

40 This had been emphasised for example by the Secretary of State in the Federal Ministry for Economic Co-operation Detlev Rohwedder at the occasion of opening the "Rand Show" in Johannesburg on 21 April 1975. He assured that the German market will always be left open for the South African firms and that the Federal Republic and South Africa can fruitfully co-operate in many fields. An example of the "fruitful co-operation" in the arms business was published by Africa No. 44 of April 1975 in an article "Bonn arms South Africa".
} 
be set backs, but what counts is the final aim: the normalization of mutual relations. This may not come to-day or even tomorrow, but it will come ${ }^{41}$ ".

The Dar es Salaam Declaration was endorsed by the twelfth OAU Summit in Kampala in July 1975 by one of the strongest worded resolutions ever adopted on South Africa. The resolution calls the Pretoria regime „a product of colonial conquest now operating as a fully-fledged fascist power bent on perpetuating the ruthless domination of the indigenous people". It rejects the "détente" as an attempt to "legitimize the oppression and exploitation of the South African people".

The recent developments in Southern Africa, notably the breakdown of the constitutional talks between African National Council (ANC) and the Government of Ian Smith at a railway wagon on the Rhodesia-Zambia border in August 1975, confirmed that "détente" as an alternative to the armed struggle in Southern Africa aimed at termination of white supremacy in Rhodeis and South Africa has utterly failed ${ }^{42}$.

\section{Conclusions}

Southern Africa is now facing a grim future with prospects of a slow war of attrition between the liberation movements in Rhodesia and the Rhodesian army and police force. There are indications that the struggle for independence of Namibia will take a similar turn. It is true that the guerrilla operations could be at this stage contained by the superior armed forces of their adversaries but it is also true that they will not cease entirely. As the violence on both sides gradually escalate, the confidence of the white minorities in Rhodesia and South Africa will be eroded. International pressure on Rhodesia and South Africa will also continue to rise. The African States will renew their demands for the expulsion of South Africa from the United Nations and they will try to dissuade the Western Powers from supporting the Pretoria regime by arms deliveries and military co-operation, a move that while not necessarily weakening the military potential of well-armed South Africa with its own armament industries, will have a great impact on the morale of its white population.

South African Prime Minister Vorster's confidence in "normalization" of South Africa's relations with Black Africa is based on an erroneous belief that the OAU members will fall out with one another and enter a dialogue with South Africa on their own. In that respect his strategy is identical with that of Ian Smith in Rhodesia. Smith, knowing the fragility of the ANC counts on the breakdown on the talks on grounds of ANC disunity, and on the possibility of making a deal with the "moderates" on his own terms.

The differences within the OAU on the "détente" with South Africa and the difficulties of maintaining ANC unity in Rhodesia are of course real and may slow down the pace of decolonisation of South Africa and temporary blunt the edge of confrontation with South Africa. But time is not on Vorster's and Smith's side and they do not have much time left. If and when the "détente" is resumed, their options will be considerably reduced.

\footnotetext{
41 Die Welt, 26. April 1975, "Vorster setzt auf den Ausgleich zwischen Süd- und Schwarzafrika."

42 The negotiations broke down on 25th August after Ian Smith declined to accept point 5 of the "Declaration of Intention to negotiate a settlement" approved by Bishop Muzorewa and President Kaunda and South African Prime Minister Vorster, namely the demand that the ANC representatives presently in exile shall enjoy full diplomatic immunity within and outside Rhodesia.
} 